\title{
Upaya Pencegahan Kecurangan Dalam Mengelola Dana Desa Sesuai Dengan Prinsip Akuntabilitas dan Transparansi
}

\author{
Fransiska Rahayu ${ }^{1}$, Luh Dina Ekasari ${ }^{2}$, Ahmad mukoffi ${ }^{3}$ \\ 1,2,3 Universitas Tribhuwana Tunggadewi \\ e-mail: unitriahmadmukoffi@gmail.com

\begin{tabular}{ccc}
\hline Diterima & Direvisi & Disetujui \\
$23-07-2021$ & $15-09-2021$ & $26-09-2021$ \\
\hline
\end{tabular}

\begin{abstract}
Abstrak Adapun tujuan dari riset ini ialah untuk mengetahui sejauh mana untuk dapat menganalisis sebuah upaya dalam pencegahan terjadinya fraud terhadap sistem pengelolaan keuangan pada desa, serta dapat mengetahui faktor pendorong serta penghambat terjadinya fraud terhadap sistem pengelolaan keuangan pada desa. Riset ini menggunakan riset kualitatif yang mana bertujuan untuk dapat melihat sejauh mana fenomena yang terjadi terkait dengan sistem pengelolaan keuangan desa. Lokasi yang akan dijadikan sumber riset ini ialah Desa sumbersekar yang beralamat di Jalan Raya Sumbersekar No. 108, Krajan, Sumbersekar, Kec.Dau Malang, Jawa Timur 65151. Data yang digunakan bersumber dari data sekunder serta data primer, teknik pengumpulan data pada riset ini ialah dokumentasi interview serta observasi. Teknik analisa data yang akan digunakan dalam riset ini ialah Pengumpulan Data, Reduksi Data, Penyajian Data sampai dengan penarikan sebuah kesimpulan yang ada. Hasil yang digukan dalam riset ini ialah desa sumbersekar telah menerapakan prinsip akuntanbilitas dalam pengelolaan alokasi dana desa pada desa sumbersekar sudah cukup baik karena melibatkan masyarakat dalam pengelolaan karena dalam pencegahan kecurangan pengeloaan dana desa sumbersekar juga telah menerapkan prinsip akuntanbilitas karena pemerintah telah memberikan informasi kepada masyarakat desa tentang dana desa juga pemerintah desa mengajak masyarakatnya peran aktif dalam pelaksanaan pengawasan kinrja pemerintah desa dalam pengelolaan dana desa dalam rencana kerja pemerintah desa selanjutnya dan dalam penggunaan dana desa.
\end{abstract}

Kata Kunci : Pencegahan Fraud Dalam Pengelolaan Keuanga Desa

Abstract The purpose of this research is to find out to what extent to be able to analyze an effort to prevent fraud against the financial management system in the village, and to know the driving and inhibiting factors for the occurrence of fraud in the financial management system in the village. This research uses qualitative research which aims to be able to see to what extent the phenomena that occur are related to the village financial management system. The location that will be used as the source of this research is Sumbersekar Village, which is located at Jalan Raya Sumbersekar No. 108, Krajan, Sumbersekar, Kec. Dau Malang, East Java 65151. The data used are sourced from secondary data and primary data, the data collection techniques in this research are interview documentation and observation. Data analysis techniques that will be used in this research are Data Collection, Data Reduction, Data Presentation to the drawing of an existing conclusion. The results used in this research are that Sumbersekar Village has applied the principle of accountability in managing the allocation of village funds in Sumbersekar Village, which is quite good because it involves the community in management because in preventing fraudulent management of Sumbersekar Village funds, it has also applied the principle of accountability because the government has provided information to the village community. Regarding village funds, the village government also invites the community to take an active role in the implementation of monitoring the village government's performance in managing village funds in the next village government work plan and in the use of village funds.

Keywords : Fraud Prevention in Village Financial Management

\section{PENDAHULUAN}

Membangun kepercayaan publik terhadap pemerintah dalam mengelola dana desa saat ini adalah sesuatu yang cukup sulit dengan keadaan saatsaat ini publik harus mengetahui kinerja apa saja yang dilakukan pemerintah. APBdesa juga dapat dikatakan sebagai salah satu anggaran yang diadakan dalam kurun waktu satu periode oleh pihak desa (Jayanti \& Suardana, 2019). Sistem pengelolaan anggaran dana desa dapat dinyatakan sebagai sebuah aktivitas yang bagian dari sistem pengelolaan dalam APBDesa, meliputi perencanaan, pelaksanaan, penataushaan, pelaporan dan pertanggungjawaban (Shuha, 2018). Salah satu teori yang dikenal dengan nama gone teori yang mana menyatakan bahwa ditemukan beberapa faktor yang menyebabkan terjadinya fraud yang mana berdasarkan pada sisi perilaku sesorang yang tidak terlepas dari peluang serta pada tingkat kebutuhannya (Santi Putri Laksmi \& Sujana, 2019). Kurangnya pemahaman memadai aparatur desa terkait pengelolaan dana desa juga akan berpotensi 
memunculkan kecurangan. (Rayyani \& Makassar, 2019).

Di Indonesia tindakan kecurangan akuntansi dapat digolangkan menjadi beberapa bagian antaralain bagian sektor suasta serta sektor publik. Menurut (Sulastri, 2014) kecurangan banyak terjadi dikalangan instansi pemerintah, karena instansi pemerintah merupakan struktur organisasi yang kompleks, sistem birokrasi yang rumit, sistem pengendalian yang rendah, dan terjadi tekanan yang tinggi. Korupsi merupakan salah satu kecurangan akuntansi yang banyak dilakukan. Korupsi muncul dinegara berkembang, karena mereka berlombalomba untuk memenuhi gaya hidup yang konsumtif, sifat yang rakus, penegak hukum yang lemah, serta rendahnya tingkat kesadaran akan moral yang baik. Pada instansi pemerintah sendiri telah banyak ditemukan tindakan korupsi, baik oleh pemerintah pusat maupun pemerintah dearah Fenomena khasus kecurangan dalam mengelola dana desa di indonesia banyak terjadi, beberapa khasus di berbagai daerah, menurut (ICW) menyebutkan bahwa ditemukan 169 permasalahan yang disebut sebagai KKN atu korupsi kalusi serta nepotisme dalam kurun waktu satu semester di tahun 2020. Berdasarkan dengan temuan yang ada kecurangan pada anggaran dana desa yang dominan ialah 44 permasalahan. (sumber Indonesia Corruption Watch, 2020).

Pihak kepolisian Negara RI yang berada di Kabupaten Tlotoli, Sulteng menyatakan bahwa tingkat terjadinya fraud terhadap anggaran dana desa serta ADD yang mana akan melibatkan pimpinan desa dalam hal ini kepala desa yang mencapai kerugian mencapai ratusan juta rupiah. Sebagaimana dengan terjadinya penyelidikan tersebut, sehingga pada Tahun 2017-2019 pihak kepolisian Negara RI telah menetapkan tersangka yang melakukan fraud terhadap ADD terhadap sarana dan prasarana dalam proses pembangunan, disamping itu sistem pembayaran pada pajak bersumber dari anggaran dana desa yang sebagaimana telah diperincikan pada beberapa tahapan diantaranya tahap kedua sama sekali tidak diadakan penyetoran terhadap kas Negara, serta tersangkan akan melakukan laporan pertanggung jawaban yang secara fiktif. (sumber kompol. Liputan6.com, Tolitoli 2020).

Sebagaimana dari sebuah fenomena yang diungkapkan terjadinya kecurangan yang aman akan terjadi di berbagai kalangan pedesaan yang berada di Kabupaten Tolitoli Sulteng.

Situasi dalam penyalagunaan fiansial DD akan berdampak hal yang negatif dalam kalangan kehidupan bermasyarakat serta bertentangan dengan pihak pemerintahan yang secara menyeluruh, akan tetapi apabila diadakan sebuah kajian yang lebih spesifik seharusnya pihak pemerintahan membuat sebauh penetapan dengan berbagai jenis aturan serta dengan petunjuk yang berkaitan dengan sistem pengelolaan ADD sehingga dapat menghambat terjadinya tindakan kecurangan yang akan terjadi.
(Alfaruqi \& Kristianti, 2019). Anggaran publik yang mana dikelolah oleh pihak pemerintah desa seharusnya mampu untuk bertanggung jawab terhadap sistem pengelola ADD baik itu kepada kalangan masyarakat pada umumnya serta pada khususnta kepada pihak pemerintah pusat (Ngakil \& Kaukab, 2020).

\section{METODE PENELITIAN}

Riset ini menggunakan riset kualitatif yang mana bertujuan untuk dapat melihat sejauh mana fenomena yang terjadi terkait dengan sistem pengelolaan keuangan desa. Lokasi yang akan dijadikan sumber riset ini ialah Desa sumbersekar yang beralamat di Jalan Raya Sumbersekar No. 108, Krajan, Sumbersekar, Kec.Dau Malang, Jawa Timur 65151. Data yang digunakan bersumber dari data sekunder serta data primer, teknik pengumpulan data pada riset ini ialah dokumentasi interview serta observasi. Teknik analisa yang akan digunakan pada riset ini ialah informasi yang diperoleh diantaranya reduksi data sampai pada penarikan kesimpulan.

\section{HASIL DAN PEMBAHASAN}

\section{Upaya pencegahan kecurangan Pengelolaan dana desa melalui Prinsip Akuntanbilitas}

Prinsip akuntanbilitas sangat penting dalam pengelolaan dana desa untuk pencegahan kecurangan. Khususnya dalam pengelolaan keuangan pada kantor desa sumbersekar. Akuntanbilitas yang dibutuhkan sebagaimana dijadikan sebuah pelaporan dalam pengelolaan ADD yang bermanfaat serta dapat dipercaya oleh pihak-pihak terkait. Sistem penerapan dalam sebuah prinsip yang namanya akuntabel pada riset ini ialah dapat bertanggung jawab pada penggunanan anggaran desa dari pemerintah. Sumber dana pada desa sumbersekar adalah dari pemerintah yang disebut APBDes dana tersebut digunakan untuk pembanguanan desa sesuai program yang telah di tetapkan dalam Musyawarah desa yang dikenal dengan nama RKPD (Rencana Kerja Pemerintah Desa) yang disepakati masyarakat. Selain itu pengelolaan keuangaan desa pada desa sumbersekar khususunya dalam melakukan kegiatan yang menggunakan dana desa pemerintah desa membentuk Tim Pelaksanaan Kegiatan (TPK). Laporan keuangan desa akan disampaikan kepada pemerintah setempat dan kepada Badan Pengurus Desa sumbersekar. Desa sumbersekar menggunakan prinsip akuntanbilitas dalam pengelolaan dana desa adalah untuk mencegah kecurangan. Keakuntanbilitas finansial di desa dapat dikelolah secara maksimal yang mana berlandasakan pada sebuah praktik pada pemerintahan yang jauh lebih efektif dalam pengelolaan keuangan desa sumbersekar bendahara desa dalam sistem pencatatannya secara manual juga sudah menggunakan aplikasi Siskeudes (Sistem Keuangan Desa) Sistem pengelolaan keuangan desa yang mana 
telah dituangkan dalam Peraturan Mentri Dalam Nege ri Tahun 2014 No 113 yang artinya : partisipasi, akuntabel serta berdisiplin dalam anggaran, yang mana dapat dibagi sebagai berikut :

a. Transparan, yaitu prinsip keterbukaan yang memungkinkan masyarakat untuk mengetahui dan mendapatkan akses informasi seluasluasnya tentang keuangan desa.

b. Akuntabel, yaitu perwujudatan kewajiban untuk mempertanggungjawabkan pengelolaan dan pengendalian sumber daya dan pelaksanaan kebijakan yang dipercayakan dalam rangka pencapaian yang ditetapkan.

c. Paratisipatif, yaitu penyelenggaran pemerintahan desa yang mengikut sertakan kelembagaan desa dan unsur masyarakat desa.

d. Tertip dan displin anggaran yaitu penggelola keuangan desa harus mengacu pada aturan atau pendoman yang melandasinya.

Dalam pencegahan kecurangan dalam mengelola dana desa pada kantor desa sumbersekar sesuai dengan akuntanbilitas yaitu keterbukaan artinya segala kegiatan dan informasi desa sumbersekar dapat upaya yang dilakukan dilihat dengan tingkat transparan, akuntabel, partisipatif, tertib dan disilpin anggaran. Dilihat dari hasil wawancara berikut upaya yang dilakukan. Sebagai mana hasil interview bersama pihak bendahara pada Tahun 2021 Tanggal 20 Mei :

Di sini kami telah menerapakan prinsip akuntanbilitas ya walaupun belum sesuai dengan keinginan masyarakat, kami telah berusahan menerapakan akuntanbilitas khususnnya dalam penggunanan dana desa dalam pembangunan desa secara fisik dan bidang pemberdayaan, masyarakat mengetahui informasi pengguanan dana desa melalui musyawarah desa, papan informasi dan benner tentang penggunanan dana desa walaupun mungkin secara akses teknologi kami belum ada blog khusus tentang informasi desa karna kurangnya tenagan ahli yang bisa menggunakannya itu membuat sulit untuk mengakses informasi desa kalau secara jarak jauh

Dengan pernyataan di atas diketahui bahwa aparat desa sumbersekar telah menerapkan prinsip akuntanbilitas pada khususnya transparan karna masyarakat sudah dengan mendapatkan informasi walaupun hanya melalui musyawarah desa, papan informasi dan benner tentang penggunanan dana desa unttuk kemudahan informasi masih sangat sulit untuk mendapatkan informasi secara jarak jauh karna belum bisa diakses secara online Sedangkan menurut wawancara dengan seketaris desa pada tanggal 15 Mei 2021:

Kami telah menerapakan prinsip akuntanbilitas dengan baik dan dengan itu masyarakat desa di sini percaya kepada kami, karna selama ini tidak pernah ada kecurangan apa pun yang terjadi di sini artinya kami udah akuntanbilitas dan transparansi dalam pengelolaan keuangan desa.

Wawancara pada 21 mei 2021 dengan pendaping desa:

Desa sumbersekar adalah desa yang saya dampingi dari tiga desa dipercayakan saya dampingi, selama saya mendapingi desa sumbersekar tidak pernah terjadi kecurangaan dan mereka selalu membuat pelaporan yang sesuai dalam pelaporan keuangan dan tidak pernah ada masalah keuangan terhadap sistem pengelolaan anggaran desa. Pada umumnya desa yang diberikan tanggung jawabab kepada saya dampingi dan termasuk desa sumbersekar menurut saya yang paling bagus pelakasanaan kegiatan dan tanggungjawabnya.

Dari hasil wawancara di atas diketahui bahwa desa sumbersekar telah bertanggungjawab dengan dana desa yang dipercayakan kepada mereka artinya merekan telah akuntabel dan bertanggungjawab dengan keuangan mereka dengan demikian upaya pencegahan kecurangan dana desa disumbersekar menggunakan prinsip akuntanbilitas dalam peratanggungjawabanya telah di terapkan sehingga sulit terjadi kecurangan karna aparat desa benar-benar bertanggungjawab dan akuntabel. Selain bertanggungjawab aparat desa sumbersekar juga mencegah kecurangan dengan Paratisipatif, karna pemerintah desa mengikutsertakan masyarakat desa dalam RKPdes yang mana telah diadakan dnegan cara melakuakn musyawarah desa yan dilakukan setiap dusun nantinya menjadi usulan prioritas kegiatan pembangunan tahun berikutnya. Sesuai dengan hasil wawancara dengan sekertaris Tahun 2021 Tanggal 15 Mei :

Kami mengadakan agenda musywarah desa dalam rencana pembangunan dan rencana kerja yang kami musywarahkan dengan masyarakat dan kami juga mengadakan musywarah tersebut pada setiap dusun agar setiap hasilnya adalah hasil bersama masyarakat dan pemerintah desa.

Paratisipatif artinya masyarakat mengetahui rencana kegiatan sudah sesuai dengan yang dianggarakan artinya masyarakat di sini berperan juga sebagai pengawas kegiatan desa memalui progrman kerja pemerintah desa yang di bahas pada musyawarah desa dengan demikian masyarakat akan mengetahui program yang telah teralisasi atau belum. Upaya pencegahan kecurangan dana desa melalui paratisipatif akan efektif jika pemerintah desa benarbenar bekerja sama dengan masyarakat dan juga masyarakat berperan aktif dalam pengawasan keuangan desa melalui akses informasi yang mereka dapat akuntanbilitas dapat tercapai jika masyarakat ikut berperan aktif di dalamnya khususnya dalam 
mengawasi anggaran yang digunakan untuk pembangunan desa. Dari hasil wawancara dengan bendahara desa 15 mei 2021:

Di dalam melaksanakan kegiatan kita sudah aku ntanbilitas karna setiap kegiatan kita membentuk tim kegiatan TPK (Tim Pelaksanaan Kegiatan) dimana kegiatan pembangunan atau kegiatan bidang perberdayaan dilaksanakan mereka yang akan membuat pelaporan kegiatan pengguanan dana desa kepada pemerintah desa.

Dari hasil wawancara di atas diketahui upaya pencegahan kecurangan dana desa menggunakan prinsip akuntanbilitas adalah peran keterbukaan pemerintah desa kepada masyarakat sangat penting dan masyarakat juga harus bereperan penting di dalam pelaksanaan kegiatan-kegiatan yang diadakan desa. Berdasarkan paparan di atas dari hasil wawancara penulis menyimpulkan bahwa:

a. Transparan : artinya keterbukaan atas segala kegiatan dan informasi terkait penggunaan dan pengelolaan keuangan desa dapat di ketahui masyarakat dimudahkan untuk dan untuk mengakses informasi tentang desa khususnya tentang dana desa secara online atau melalui internet belum bisa dengan demikian upaya pencegahan kecurangan melalui proses transparan adalah informasi perhial pengelolaan alokasi dana desa yang mudah dimengerti dan masih sulit di akses secara online atau melalui intrenet.

b. Akuntanbilitas : artinya pemerintah desa pertanggungjawab dengan pengelolaan dana desa khusunya dalam bidang pembangunan desa dan bidang pemberdayaan. Dengan demikian artinya pemerintah desa bertanggung jawab kepada masyarakat yang memiliki hak dan kewajiban untuk meminta keterengan akan pertanggungjawban.

c. Paratisipasif : di sini desa telah melibatkan masyarakat dalam proses Rencana kerja pemerintah, jadi masyarakat sering dilibatkan dalam kegiatan desa dan masyarakat berperan penting dalam pengawasan keuangan.

d. Disiplin serta tertib dana hal tersebut perlu dibuat oleh pihak pemerintahan dalam hal ini pemerintah desa berdasarkan dengan mekanisme serta tata cara dalam melaksanakan dengan pengertian bahwa anggaran harus dilaksanakan secara konsisten dengan pencatatan atas pengguaannya sesuai dengan prinsip akuntansi keuangan desa.

Upaya Pencegahan Kecurangan Pengelolaan Dana Desa Melalui Prinsip Transparansi

Transparansi merupakan prinsip Keterbukaan merupakan salah satu cara yang dapat menjanjikan kebebasan terhadap setiap orang dengan mendapatakan informasi khususnya informasi tentang penggunanan dana desa dengan tujuan agar dapat menilai sebuah data yang valid, oleh karena itu dapat dibedahkan menjadi beberapa bagian, antara lain :

a. Tata cara yang akan menjanjikan dalam sebuah transparansi dalam sebuah standar beradasarkan dengan berbagai jenis proses dalam sebuah pelayanan terhadap publlik

b. Dalam tata cara untuk dapat memfasilitasi dengan berbagai jenis pertanyaan pubik terhadap berbagai jenis kebijakan serta mekanisme terhadap pelayanan publik

c. Tata cara yang dapat memfasilitasi sebuah pelaporan serta penyebaran data yang dapat menyimpang merupakan salah satu tindakan dalam melakukan pelayanan

Tingkat transparansi dalam pengelolaan ADD adalah upaya dalam melakukan pencegahan terjadinya kecurangan terhadap sistem pengelolaan anggaran desa, dapat dinyatkan dalam 3 faktor antara lain : sistem yang transparansi, tata cara menfasilitasi berbagai pertanyaan serta tata cara dalam melakukan sebuah pelaporan yang adanya kejanggalan oleh pihak pemerintah desa.

Berdasarakan hasil interview yang dibuat oleh pihak pemerintahan dalam hal ini pemerintah desa dan pendaping desa mengatakan desa sumbersekar telah melakukan transparansi, karna pemerintah telah melakukan transparansi yang secara efektif serta tuntunan pemerintah, terhadap mekanisme akan selalu mendengarkan berbagai jenis keluhan serta pernyataan-pernyataan yang ada dikalangan masyarakat melalui musyawarah desa degan masyarakat dalam rangka perencanaan ADD untuk melaksanakan pembangunan di desa, juga dalam sistem sebuah pelaporan pihak pemerintah desa sepenuhya dapat memberikan secara keseluruhan anggaran desa yang akan dipergunaan dalam pembangunanan desa dan dalam bidang pemberdayaan desa sumbersekar sedangkan dalam pelaporan ke pusat dilakukan berdasarkan dengan Undang-undang. Hal ini dilakukan desa sumbersekar adalah sebagai upaya pencegahan kecurangan dan membuktikan desa sumbersekar telah transparansi dalam penggunakan dana desa yang ada. Hal tersebut berdasarkan hasil wawancara dengan aparat desa pada tanggal 22 mei 2021:

Kami selaku aparat desa menerapakan transparansi di desa ini, kami terbuka dengan masyarakat seluruh masyarakat desa tentang pengelolaan keuangan dana yang dibutuhkan dalam pembangunan. Kami menyampaikan informasi pengunanan dana desa yang digunanakan pembangunan desa kami menyapaiakan saat ada musyawarah desa. Kami melakukan semuanya itu adalah upaya kami untuk mencegah kecurangan dan kami tidak mau menimbukan masyarakat kepada aparat desa. 
Sedangkan hasil wawancara dengan aparat desa 18 mei 2021:

Kami menerapakan transparansi khususnya dalam bidang perencanaan yang menggunakan dana desa, agar masyarakat merasa memiliki dana desa tersebut dengan demikian masyarakat akan merasa bertanggungjawab juga dalam pengawasan penggunannya.

Begitu juga yang dikatakan aparat desa pada tanggal 20 mei 2021 :

Ya pastinya kami transparan, makanya kalau APBDes keluar kami langsung benner seperti yang ada pada pintu masuk, transparan adalah kunci supaya terhindar dari kecurangan. makanya kami tidak ada khasus kecurangan karna kami transparan dari atas sampai bawah kami juga bekerja sama dengan pihak RT dan RW setempat.

Berdasarkan paparan di atas sesuai dengan 3 mekanisme di atas maka hasil wawancara terkait penerapan transpransi dalam upaya pencegahan kecurangan dana desa adalah:

a. Mekanisme yang menjanjikan sebuah keterbukaan desa sumbersekar dalam menjalakan transparansi serta melakukan standarisasi berdasarkan seluruh proses dalam pelayanan publik dalam hal ini pihak pemerintah desa seumbersekar sudah menjalakan keterbukaan kepada masyarakat dalam pengelolaan alokasi DD perlu diketahui oleh kalangan masyarakat pada umumnya, sehingga tidak ada terjadinya kejanggalan dalam proses pembangunan dalam desa.

b. Tata cara yang baik untuk dapat memfasilitas dengan berbagai jenis pertanyaan terkait dengan sistem kebijakan dalam pelayanan publik serta sebuah proses dalam sektor publik, dalam hal ini pihak pemerintah desa sumbersekar selalu akan melibatkan msyarakat desa dalam musyawarah desa disetiap kegiatan sehingga pertanyaan pertanyaan masyarakat kepada pemerintah desa dapat terjawab.

c. Tata cara yang baik untuk dapat memfasilitasi sebuah pelaporan serta data yang terjadinya penyimpangan yang dilakuakan oleh publik dalam hal ini pihak pemerintah desa menyampaiakan apabila ada terjadi penyimpangan hal itu dilakukan agar masyarakat merasa sama-sama bertanggungjawab dengan keuangan desa dan pengelolaan penggunanya.

\section{Pembahasan Hasil Penelitian}

Dalam pembahasan yang ada serta dari hasil riset yang telah dipaparkan oleh peneliti, sehingga dapat diuraikan dalam penulisan ini ialah upaya pencegahan kecurangan dalam pengelolaan dana desa menggunkan prinsip akuntanbilitas dan transparansi pada kanor desa sumbersekar kecamantan dau jawa timur diantaranya :

1. Dalam sistem pengelolaan anggaran desa pemerintah desa sumbersekar sudah akuntanbilitas upaya pencegahan kecurangan yang dilakukan menggunakan prinsip akuntanbilitas adalah memberikan informasi tentang penggunanan dana desa.

2. Membuat pertanggungjawaban tentang penggunaan dana desa, Pemerintah desa bekerja sama dengan masyarakat dan juga masyarakat berperan aktif dalam pengawasan keuangan desa melalui akses informasi. Desa sumbersekar telah menerapakan prinsip akuntanbilitas dalam pencegahan kecurangan pengelolaan dana desa, tetapi desa sumbersekar belum benar-benar mempermudah masyarakat mengetahui informasi desa karna sulitnya akses informasi karna informasi hanya di sampaikan melalui papan informasi dan benner tetapi belum bisa di akses melalui internet atau blog khusus desa sumbersekar.

3. Upaya pencegahan dalam mengelola dana desa dengan prinsip transparansi dapat di liat dari ketiga mekanisme :

a. Tata cara yang akan menjamin keterbukaan dan standarisasi berdasarkan dengan seluruh proses dalam pelayanan publik ialah keterbukaan kepada masyarakat dalam pengelolaan DD perlu diketahui oleh kalangan masyarakat pada umumnya, sehingga tidak terjadinya unsur kecurigaan terhadap pihak pemerintah desa yang ada.

b. Tata cara yang akan memfasilitas dengan berbagai jenis pertanyaan publik terkait dengan berbagai jenis kebijakan dalam pelayanan publik serta selalu terlibat aktif dalam musyawarah desa dan disetiap kegiatan sehingga pertanyaan-pertanyaan masyarakat kepada pemerintah desa dapat terjawab.

c. Tata cara yang akan menfasilitasi terhadap sebuah pelaporan serta penyimpangan dalam penyebaran data serta penyimpangan sebuah tindakan pihak pemerintah desa dalam aktifikan pelayanan publik terkait dengan situasi atau masalah kecurangan apabila ada terjadi pada masalah desa sumbersekar

\section{KESIMPULAN}

Upaya pencegahan kecurangan dalam pengelolaan dana desa melalui prinsip akuntanbilitas dan transparansi adalah sebagai berikut:

1. Kantor desa sumbersekar telah menerapakan prinsip akuntanbilitas terhadap sistem pengelolaan DD pada desa sumbersekar dapat dinyatakan efektif karena pihak pemerintah desa secara langsung melibatkan seluruh masyarakat dalam pengelolaan karena dalam pencegahan 
kecurangan pengeloaan dana desa sumbersekar juga telah menerapkan prinsip akuntanbilitas karena pemerintah sudah dapat memberikan semua data terhadapat masyarakat desa juga pemerintah desa mengajak masyarakatnya peran aktif dalam pelaksanaan pengawasan kinrja pemerintah desa dalam pengelolaan dana desa dalam rencana kerja pemerintah desa selanjutnya dan dalam penggunaan dana desa.

2. Kantor desa sumbersekar telah menerapkan prinsip transparansi yang sudah cukup baik karena dalam pencegahan kecurangan pihak pemerintah desa sumbersekar yang mana akan menerapkan sebuah prisnsip ketransparan terhadap sistem pengelolaan DD dapat di lihat dengan cukup mudah masyarakat mendapatkan informasi tentang dana desa, pemerintah desa juga bertanggungjawab apabila ada masalahmasalah yang terjadi pada desa sumbersekar.

\section{REFERENSI}

Alfaruqi, I., \& Kristianti, I. (2019). Analisis Potensi Kecurangan Dalam Pengelolaan Keuangan Desa (Studi: Desa Kesongo, Kecamatan Tuntang, Kabupaten Semarang, Jawa Tengah). Jurnal Akuntansi Maranatha, 11(2), 199-210. https://doi.org/10.28932/jam.v11i2.1915

Jayanti, L. S. I. D., \& Suardana, K. A. (2019). Pengaruh Kompetensi SDM, Moralitas, Whistleblowing dan SPI Terhadap Pencegahan Fraud Dalam Pengelolaan Keuangan Desa. EJurnal Akuntansi, 29(3), 1117. https://doi.org/10.24843/eja.2019.v29.i03.p16
Ngakil, I., \& Kaukab, M. E. (2020). Transparansi dan Akuntabilitas Pengelolaan Keuangan Desa di Kabupaten Wonosobo. Journal of Economic, Management, Accounting and Technology, 3(2), 92-107. https://doi.org/10.32500/jematech.v3i2.1283

Rayyani, W. O., \& Makassar, U. M. (2019). Menguak Implementasi Prinsip Good Government Governance Dalam Pengelolaan Dana Desa: Sebuah Upaya Pencegahan Fraud. AkMen Jurnal Ilmiah, 16(3), 342-354.

Santi Putri Laksmi, P., \& Sujana, I. K. (2019). Pengaruh Kompetensi SDM, Moralitas dan Sistem Pengendalian Internal Terhadap Pencegahan Fraud Dalam Pengelolaan Keuangan Desa. E-Jurnal Akuntansi, 26, 2155. https://doi.org/10.24843/eja.2019.v26.i03.p18

Shuha, K. (2018). Analisis Pengelolaan Desa ( Studi Kasus pada Desa-desa Selingkungan Kecamatan Lubuk Alung Kabupaten Padang Pariaman ). Universitas Negeri Padang, 1-21.

Sulastri, S. (2014). FRAUD PADA SEKTOR PEMERINTAH BERDASARKAN FAKTOR KEADILAN KOMPENSASI, SISTEM PENGENDALIAN INTERNAL, DAN ETIKA ORGANISASI PEMERINTAH (Studi Empiris Dinas Pemerintah Provinsi DKI Jakarta). Jurnal Magister Akuntansi Trisakti, 1(2), 199. https://doi.org/10.25105/jmat.v1i2.4938 